i śmierci Boskiego Odkupiciela, powołać rząd, oparty na prawie międzynarodowym, który by wobec obecnego stanu rzeczy troszczył się, jak najbezpieczniej i najlepiej ustrzec wspomniane pamiątki. Niechby także tym prawem międzynarodowym udogodniono bezpieczną drogę do miejsc świętych i zapewniono zupełną swobodę iw odprawianiu świętych obrzędów i nie naruszano zwyczajów, odziedziczonych w spuściźnie po przodkach.

Oby za wolą Bożą jak najprędzej zajaśniał dzień, by chrześcijanie mogli znowu podejmować pielgrzymki do miejsc świętych, a rozmyślając nad dowodami miłości Jezusa Chrystusa, który dla zbawienia braci oddał Swoje życie, jaśniej się pokazało, jak ludzie i narody uspokoiwszy swoje umysły i uporządkowawszy wzajemne stosunki, powinny współżyé razem.

W tej nadziei udzielamy Wam Bracia Czcigodni i Waszej trzodzie, jak również tym wszystkim, którzy chętnym umysłem przyjmą nasze upomnienia, Apostolskiego Błogosławieństwa, jako zapowiedzi łask Bożyçh i dowód Naszej życzliwości.

Dan na zamku w Castel Gandolfo koło Rzymu w dniu 24-go października 1948 r., pontyfikatu naszego dziesiątego.

PIUS P. P. XII.

\title{
O HISTORIOGRAFII BIBLIJNEJ I STAROWSCHODNIEJ
}

Wśród pism biblijnych Starego Testamentu mamy szereg takich, które ząlicza się do Ksiąg historycznych. Nazwa ta im przysługuje, aḷowiem autorowie biblijni mieli na celu przedstawić dzieje narodu swego zgodnie $z$ historyczną prawdą i w kolejności historycznych wydarzeń. Ale samo tylko przedstawienie dziejów narodu izraelskiego nie było jedynym i głównym celem autorów biblijnych. Pisma ich nie miały służyć celom naukowym ani dostarczać materiału naukowego o charakterze antykwarskim. Autorowie tych pism chcieli raczej przedstawić Dzieje Ś Sięte w taki sposób, aby służyć mogły celom religijnowychowawczym.

Kiedy Mojżesz nakazuje Iźraelitom zachowanie świąt, szczególnie święta Paschy po wieczne czasy, i to w ziemi palestyńskiej, którą mają wziąc w posiadanie jako ziemię obiecaną, dodaje Mojżesz: „Jeżeli dzieci wasze zapytaja się was: Co to macie tam za zuyczaj-tedy im odpo- 
wiecie: Oto jest ofiara Paschy dla Pana, który przeszedl w Egipcie obok mieszkań Izraelitów, kiedy ukarat Egipcjan, a domy wasze ocalit" (Ex. 12, 24-27).

Po przejściu przez rzekę Jordan każe Jozue 12 kamieni zabrać z Jordanu i ustawić je w Gilgala. I rzekł do Izraelitów: „Kiedy później dzieci wasze ojców swoich zapytaja: Jakie znaczenie haja te kamienic? tedy macie dać dzieciom waszym takie wyjaśnienie: Sucha noga przeszedt tu Izrael przez Jordan, albowiem Pan, Bóg wasz, osuszyl wody Jordańskie przed wami, ażeście przeszli, jak to uczynit Pan, Bóg wasz, przy morzu sitowia (tj. Czerwonym), które wysuszył przed nami, ażebyśmy przeszli“ (Joz. 4, 20-23).

Podobnie jak o tych dwóch wydarzeniach opowiadano sobie wśród rodzin izraelskich i o innych sprawach. Cała przeszłośé Izraela była treścią takiej ustnej tradycji, nim została ona špisana przez powołane do tego osobistości. Celem tak tradyç̋i ustnej jak i później spisanej było wychowanie religijno-moralne.

Dziejopisarze Starego Testamentu rozmyśliwali nad przeszłością swego narodu w świetle religijnym, jak to Bóg kierował losami ludu izraelskiego, jak się nim opiekował, jak go upokarzał i znowu do laski przywłacał. Pisma o treści historycznej, począwszy od ksiegi Jozuego aż do drugiej (według Wulgaty: czwärtej) księgi Królów noszą w hebrajskim Kanonie Pism nazwe „Nebi'im“, tj. „Prorocy“. Nazwane tak zostały, nie jakoby zajmowały sie znanymi postaciami w dziejach Izraela „Prorokami“ zwanymi, ale dlatego, że autorowie biblijni, pisząc dzieje swego narodu, czyli przeszłóść jego tak przedstawili, jak właściwi Prorocy widzieli i przedstawiali pr z ýs z ło ść ludu izraelskiego. Autorzy tych Pism historycznych pouczali współezesnych im czytelników, dláczego Izrael miał niepowodzenia, dlaczego popadał w czasòwą niewolę, dlaczego zakończyły się jego dzieje taką katastrofą, jak zniszczeniem Jerozolimy, świątyni i niewolą babilońską. Na przykładach wziętych $z$ historii wykazują oni, że tak stać się musiało, bo Izrael nie zachował wierności Panu Bogu swemu, który go wyróżnił wśród innych narodów, powołując go do tak zaszczytnego zadania, że on jedyny wśród plemienia ludzkiego odebrał najdroższy skarb, $\mathrm{t} j$. wiarę $w$ jedynego prawdziwego Boga, który w dziejach okazywał mu tyle dobroci i łask.

Trafnie charakteryzuje naród swój Prorok Izajasz:

„Jam (BOG) dzieci wychowat i wynióst je wysoko, a one mnie zdradzity. 
Wót poznaje gospodarza swego,

a osioł żłób suego pana,

ale Izrael znać mnie nie chce,

lud mój nie chce mnie zrozumieć!

O biada ludowi grzesznemu,

narodowi, co peten-jest win,

plemieniem nędzników,

synem marnotrawnym" (Iz. 1, 2-4).

Dźiejopisarstwo Starego Testamentu - to nie historiografia w dzisiejszym znaczeniu. Do zadań dzisiejszego historyka należy wszechstronne zbadanie wszelkiego materiału, stojącego mu do dyspozycji, aby na jego podstawie dać możliwie jak najwierniejszy obraz dziejów danego narodu i epoki. Wydarzenia o historycznym znaczeniu, które składają się na daną epokę, historyk winien wyjaşnić w ramach możliwości, wykazać przyczyny, które je spowodowały. Starożytny zaś historyk nie znał jeszcze dzisiejszej metody badania przeszłości. Zadawalniał się on kilku źródłami, zbadał je, aby mieć obraz o przebiegu wydarzeń, a nastepnic przedstawił je w formie przystępnej swoim czytelnikom. Tak wskazuje autor Ksiąg Królew skich na księge dziejów Salomona, na Dzieje królów Judy, królów Izraela; autor Ksiąg Kroniki wylicza cały szereg źródeł, z których korzystał, a pewno czerpał swe wiadomości i z innych pism, chociaz ich wyraźnie nie cytúje ani nie wymienia.

Opowiadania są często przeplatane mowami ułożonymi przez. autorów samych, w których ilustrują ówczesne stosunki; mowy te kładą w usta swych bohaterów wzgl. osób w toku akcji występujących, które wyrażają tu swoje uczucia i zamiary. Historyk starożytny chciał zajmująco opisywać i pouczać. Podobnymi motywami kierował sie i historyk St. Testamentu. Chciał pouczać w sprawach religijnych i o rżeczach ściśle z nimi związanych, napominać, ostrzegać i wstrząsać sumieniami. Ten to cel wpłynął i na wybór materiału jak i na sposób jego przedstawienia. Autor II. ksiegi Mach. $(2,25)$ dał temu wyraz słowami: ,Natośmy skierowali nasza uwage, aby czytelnikom $i$ przyjaciołom naszym sprawić przyjemna rozrywkę, uczacym się zaś pomoc dia pamiẹci, jednym stowem wszystkim czytelnikom chcemy przynieść pozytek".

Do jakiej doskonałości pod tym względem wyrobił się historiograf biblijny St. Testamentu, można sprawdzić na Księach Samuela. Autor biblijny, przedstawiając życie i wydarzenia na dworze królów 
Saula i Dawida, objawia tu znawstwo dusz jak i przedziwną umiejętność kreślenia charakterów. Historyk E. Meyer sądzi, że wiadomości zebrane przez autora biblijnego o historii Dawida polegają na dokładnych informacjach o stosunkach panujących na dworze królewskim, jak i o charakterze i intrygach osób działających... Podziwiać trzeba autora biblijnego, który zdołał stworzyć takie dzieło o historycznej wartości. Wyróżnia się ono spośród historiografii całego starożytnego Wschodu ${ }^{1}$ ). Nie inaczej sądzą krytycy o opowiadaniach záwartych w pierwszych księgach St. Testamentu, t. zw. Pentateuchu. Autor rozpatruje w nich nie tylko wydarzenia dziejowe ze stanowiska religijnego, on działa i na uczucia religijne swych czytelników przedziwnym artyzmem sztuki pisania ${ }^{2}$ ).

Chcąc należycie ocenić historiografię biblijną, trzeba poświęcić niecoś uwagi dziejopisarstwu narodów, z którymi dawniejsi Izraelioi bliżej się byli zetknęli. Do nich należeli Egipcjanie, Babilończycy, Asyryjczycy, w mniejszej mierze Hetyci, którzy stworzyli byli wielkie państwa i znani są z swej kultury. Napisy na ścianach świątyń lub w grobowcach egipskich, opowiadające o wyprawach wojennych, wzniesieniu wielkich pałaców i świątyń mają na celu sławienie królów, książąt i bogów. Napisy te polegają na urzędowych zapiskach, o czym świadczą daty ekspedycyj wojskowych, wyliczanie jeńców i łupu zdobytego ${ }^{3}$ ). Także w starożytnej Babilonii, już wtedy, kiedy panami. tych ziem byli jeszcze Szumerowie, sporządzali nadworni pisarze zapiski, pisăli kroniki o dziełach swych władców. Z jakim zapałem i zainteresowaniem już wówczas na ziemiach starożytnego Wschodu zajmowano się przeszłością historyczną, osądzić można z przykładu króla Nabonida (555—538) z epoki neobabilońskiego państwa. Jak nowoczesny archeolog, badał on wszelkie napisy w starych świątyniach, zagrzebane $w$ ich fundamentach, a pochodzące $z$ czasów jego przodkówkrólów, panujących w Babilonie. Cizytamy np. o nim, że nie mogąc sam odnaleźć dokumentu założenia świątyni boga Szamasz w mieście Sippar, zwolał on starszych miasta oraz uczonych i nakazał im odszukać pożądany przez niego dokument $\left.{ }^{4}\right)$. Znów na innym miejscu dowiadujemy się, że koniecznie chciał wiedzieć datę panowania wielkiego króla Naramsina, jednego z następc6́w Sargona Starszego. Ba-

1) Die Israeliten u. ihre Nachbarstämme, 1906, str. 485.

$\left.{ }^{2}\right)$ E. Sellin, Einleitung in d. A. T., 1914, str. 37.

$\left.{ }^{3}\right)$ Erman-Ranke, Aegypten, 1923, str. 396.

4) B. Meissner, Babylonien u. Assyrien II, str. 330 . 
dania jego doradców ustaliły, że od czasu panowania tegoż władcy upłynęło 3200 lat $^{\circ}$ ). Historycy nowsi zauwáżyli, że król ten pomylił się o jakie 1000 lat; na obliczeniach uczonych babilońskich nie zawsze więc można polegać; źródła, na których się oni opierali, nie są tak bezwarunkowo pewne $\left.{ }^{6}\right)$. Podobne braki stwierdzono w chronologii staroasyryjskiej epoki ${ }^{7}$ ). Ustalenie chronologii starożytnego Wschodu natrafia dlatego na wielkie trudności, ponieważ stałej ery wtenczas jeszcze nie było ${ }^{8}$ ). W Babilonii np. liczono aż do czasów dynastii Kasytów (początek 2 tysiąclecia) według ważnego wydarzenia, które zawsze było w roku poprzednim; podobnie liczono w Egipcie az do XII. dynastii ${ }^{9}$ ) (ok. 2000 przed Chr.). Później datowano w Babilonii według lat panującego króla $\left.{ }^{10}\right)$, zaś w Asyrii liczono stale według t. zw. eponymów, to znaczy wysokich urzędników, rokrocznie wybieranych, według których oznaczano lata panowania danego króla. Okolicz̀nóści te i braki utrudniają również ustalenie chronologii epoki przedkrólewskiej w St. Testamencie; dopiero okres królów Izraela zdołano ująć w·ramy ściślejszego datowania dzięki ustaleniu chronologii nowoasyryjskiej epoki ${ }^{11}$ ).

Ale nie tylko zachowały sie nam suche katalogi panujących królów lub roczniki, upstrzone czasami opisem gór i przepaści, przez które przeprawiały się wojska asyryjskich zdobywców ${ }^{12}$ ). Weześnie już zainteresowano się niektórymi postaciami historycznymi lub ważnymi wydarzeniami, które wzbudziły podziw u współczesnych i późniejszych pokoleń. Taką postacią był np. Sargon Starszy (ok. 2360 r.), wódz semickich plemion, Akkadami zwanych, który założ w Babilonii i na ziemiach sąsiednich pierwsze imperium. Epizody $z$ jego życia, jego tajemnicze pochodzenie i cudowne ocalenie ${ }^{13}$ ), jego wyprawa do Azji Mniejszej stały się tematem utworów literackich. które nie można zaliczyć do pism o ściśle historycznym charakterze.

b) St. Langdon, Die neubabylonischen Königsinschriften 1912, str. 226. II. 36 .

6) Meissner 1. c. II, 363.

i) J. Lewy w Zeitschr. f. Assyr. N. F. t. 38, str. $95 \mathrm{nn}$.

$\left.{ }^{8}\right)$ M. Noth, Die Welt des A. T., 1940, str. $185 \mathrm{n}$.

$\left.{ }^{9}\right)$ A. Moret, Histoire de l'Orient - t. I. - 1936, str. 112 n.

10) por. II Reg. 25, I.

11) M. Noth 1. c., str. 189.

${ }^{12}$ ) por. Th. Dangin, Une relation de la $8 \mathrm{e}$ campagne de Sargon 713 av. J. Ch. 1912.

$\left.{ }^{13}\right)$ H. Winckler, Keilinschr. Textbuch zum A. T., 1909, str. 2 n. 
Nie można im jednak odmówić wszelkiej wiarogodności, jak to czyni krytyka np. z utworem znanym u asyriologów pod nazwą ,,szar tamhari - król bitwy" $\left.{ }^{14}\right)$. Pismo to przedstawia wyprawę króla Sargona do Azji Mn. Z braku oficjalnych dokumentów nie da się stwierdzié, czy Sargon rzeczywiście dotarł aż na daleki zachód. Tekst wspomina o różnych przygodach, dlatego też Weidner ${ }^{15}$ ) nazwał utwór hístoryczną legendą. Jednak uwzględniając, że utwór znany był również u Hetytów ${ }^{16}$ ), którzy w Azji Mn. założyli byli wielkie państwo, dalej że tekst wspomina $\mathrm{m}$. in. miasto $\mathrm{B} /$ Puruszhanda, znane także $\mathrm{z}$ dokumentów odnalezionych w Kültepe, tj. starożytne Kanisz, miejscowości w Azji Mn., gdzie w 3 tysiącleciu przed Chr. założona została kolonia składająca się z semickich Babilończyków ${ }^{17}$ ), nie można poddawać w wątpliwośé, że król Sargon faktycznie wyprawił się do Azji Mn.

Rozwiodłem się nieco szerzej nad tym utworem babilońskim dlatego, że krytycy łatwo odmawiają charakteru historyczności wydarzeniom opisanym w Pismach biblijnych, jak w księdze Rut, Tobiasza, Judyty, Estery. Opisy wydarzeń w tych księgach, napisanych w celach réligijno - wychowawczych, mogą być w szczegółach upiększone, urozmaicone, jednak nie można odmawiać wiadogodności przedstawionym faktom.

-... W związku z powyższymi metodami warto zwrócić uwagę jeszcze na jeden szczegół. Krytyka wskazuje na pewne nieścisłości historyczne w Pismach St. Testamentu, jak np. w Księdze Tobiasza 1, 18, według której uchodzi asyryjski król Sanherib jako syn Salmanasara, gdy w rzeczywistości był on synem Sargona, tj. następcy Salmanasara. Pominąwszy tę okoliczność, że tekst tego pisma zachował się nam tylko w języku greckiłm, tak, że nie można sprawdzić, jak brzmiał tekst oryginalny ${ }^{18}$ ), wskazać należy na analogiczne nieścisłości zachodzące w tekstach niebiblijnych. Otóż znany jest w dziejach starobabilońskich poza Sargonem Starszym, o którym wyżej była mowa, jeden $z$ jego następców: Naramsin. Tenże Naramsin uchodzi w jednym $\mathrm{z}$ tekstów babilońskich jako ,syn“ Sargona, chociaż rzecz ściśle historycznie biorąc, nie był on jego synem. Jeszcze ciekawszą rzecz zauważamy w wersjach o historycznym ministrze asyryjskim, znanym Achikarze.

14) Zeitschr. f. Assyr. t. VIII - 1934 - str. 21 n. 86 n.

$\left.{ }^{15}\right)$ Boghazköi-Studien III, str. 76.

16) Zeitsch. f. Ass. t. X, str. $45 \mathrm{nn}$.

17) Boghazk. Stud. III, str. $98 \mathrm{n}$.

18) J. Goettsberger, Einleitung in d. A.' T. 1928 , str. 175. 
Wersja starsza, t. zw staro-aramejska, jak ją reprezentuja dokumenty odnalezione w Elefantine w poludniowym Egipcie, podaje zgodnie z dokumentami asyryjskiemi, że Asarhaddon, król'Asyrii, był synem króla Sanheriba; natomiast późniejsza, arabska wersja, przedstawia stosunek odwrotnie, gdzie Asarhaddon jest ojcem Sanheriba ${ }^{19}$.

Starowschodni dziejopisarze, podobnie jak biblijni autorzy, zastanawiali się nad głębszą przyczyną ważniejszych wydarzeń historycznych. Wiadomo, jak ważną rolę w religijnym i politycznym życiu narodów starowschodnich odḡrrywal kult zewnętrzny, obchód świąt, składanic ofiar, śpiew, procesje, mantyka itp. Według wyobrażeń babilońskich stworzyli bogowie człowieka, żeby załatwiał ich ,służbę“ (dullu), t. j. kult, a oni sami zażywać mogli spoczynku ${ }^{20}$ ). I tak rozpatruje autor ciekawego dokumentu babilońskiego. znanego u asyriologów pod nazwą, ,kronika Weidnera" przyczyny klęsk i niepowodzeń, jak i dobrobytu w Babilonii. Wszystko zależy od ustosunkowania się tamtejszych władców do kultu boga Marduk, głównego bóstwa Bàbilonu. Królowie, którzy pod tym względem dopuścili się wykroczeń, utracili według autora swój tron; natomiast ludzie niskiego pochodzenia, którzy faworyzowali ten kult, zostali według jego zapatrywań wyniesieni na tron królewski ${ }^{21}$ ). Wielki najazd barbarzyńskich szczepów gutejskich na urodzajne ziemie Babilonii, upadek dynastii Akkadów, przypisuje autor winie króla babilońskiego Naramsina. Przeciw niemu rozgniewał się Marduk i zesłał za karę wspomniany najazd barbarzyńców ${ }^{22}$ ).

Analogiczną kwalifikację władców mamy w ksiegach biblijnych, t. zw. Królewskich. Czytamy tam powtarzającą się formułkę naganną, że ten a ten z królów izraelskich ozy judzkich ,,czynił co Bogu niemiło; nie odstąpił od grzechów Jeroboama, syna Nabata, do których ten był zwiódł Izraela“. Jak wiadomo, po śmierci króla Salomona dokonał siẹ rozłam między północnymi izraelskimi a południowymi judzkimi pokoleniami. Na czele pólnocnych stanął Jeroboam i, aby odzwyczaić podwładnych tego nowego państwa od pielgrzymek do centralnej świątyni w Jeruzalem, zaprowadził na swoich ziemiach kult cielców złotych i przyspieszył paganizację ludu ${ }^{23}$ ). Kult zewnętrzny był równiė praktykowany u Izraela i został zalegalizowany prawem Mojżeszowym.

$\left.{ }^{19}\right)$ B. Meissner w "Der Alte Orient" t. 16, str. $20 \mathrm{nn}$.

20) Keilschrifttexte aus Assur relig. Inhalts 1919, Nr 164, wiersz 6.

${ }^{21)}$ Zeitschr. f. Ass. t. VII, 1934, str. 15.

22) Tamże str. 35 i 75.

${ }^{28}$ ) Szanda, Die Bücher der Könige I. XXIV n. 
Ale przeciw jednostronnemu podkreślaniu kultu zewnętrznego na modłę pogańską powstała od razu reakcja ze strony Proroków:

„Cóż mi po mnóstwie ofiar waszych? - mówi Pan.

Dość się najadlem baranów ofiarnych i tluszczu cielat tuczonych.

Krwi bydląt, jagniąt $i$ kozlów nie pragnę...

Obrzydliwosciq jest mi dym kadzielny!...

Tych nowi $i$ świąt waszych ma dusza nienawidzi.

Staly się dla mnie nieznośnym ciężarem...

Toć mnóżcie pacierze,

Ja stuchać nie będę -

Ręce wasze pelne krwi!...

Przestancie czynić, co jest zle,

A uczcie się czynić co dobre!

Kierujcie się sprawiedliwościq,

Poskromcie krzywdzicieli,

Brońcie sierót, brońcie udów!“

$$
\text { (Iz. 1, 11-17). }
$$

Słów Proroka nie należy rozumieć w tym znaczeniu, jakoby pragnął on kult ówczesny zupełnie wyeliminować z życía religijnego. Izajasz, jak i inni Prorocy domagali się, żeby zewnętrzne objawy religijne były w najlepszej harmonii i zgodzie $z$ wewnętrznym usposobieniem i etycznym życiem każdego Izraelity. Jeżeli autor ksiąg Królewskich gani wielu $\mathrm{z}$ królów za uprawianie lub tolerowanie nielegalnego kultu, to objęte są tą naganą i inne wystẹpki, mierzące w ogóle w zakon ustanawiony pızez Bơga na górze Synaj (por. historię o królu Achabie I Reg. 16, 29 nn. 18, 18; 21).

Jest to $\mathrm{z}$ punktu widzenia historyka $\mathrm{w}$ dzisiejszym znaczeniu jednostronna ocena ludzi, bo widziana tylko ze strony religijnej. Podobnie charakteryzują grecki dziejopisarz Herodot jak i powiastki egipskie niektórych faraonów, których uważa się aż do czasów powstania piramid jako pobożnych, zaś od tego okresu uchodza oni za bezbożników $\left.{ }^{24}\right)$. Chcąc jednak być sprawiedliwym, wskazuje autor biblijny na dzieło, z którego czerpał wiadomości hïstoryozne, o ile wchodziły w zakres jego rozpatrywań religijnych; ktoby więc był zainteresowany innymi dziełami danego króla izraelskiego wzgl. judzkiego, wchodzącymi może w zakres kultury narodowej, może się informować

${ }^{24)}$ Orientalistische Literaturzeitung 1923, kol. $101 \mathrm{nn}$. 
w cytowanym przez niego dziele (np. II Reg. 24, 5 etc.) Takich wskazówek brak natomiast u autora babilońskiego.

Wiele z literatury babilońskiej przejęli wspomniani już wyżej Hetyci ${ }^{25}$ ), którzy w pierwszej połowie 2 tysiąclecia przed Chr. wtargnęli od zachodu do Azji Mniejszej i założyli tu wielkie państwo. Zachowały się w ich archiwum w dawniejszej stolicy Hattuszasz, (dzisjejsza wioska Boghazköi) historyczne dokumenty, jak roczniki królów hetyckich; szczególnie ważne dla historyka są wstẹpy historyezne w odñośnych dokumentach oraz różne dekrety królewskie ${ }^{26}$ ).

Ciekawe zainteresowanie budzi kilka tekstów hetyckiego króla Murszilisza II. (14 wiek przed Chr.) ${ }^{27}$ ). Ujęte są one w formie modlitwy, stanowią raczej jakieś egzorcyzmy dla wypędzenia dżumy, zarazy, przywleczonej do kraju Hetytów przez jeńców egipskich, zajętych podczas walk toczących się długie lata między Hetytami a Egipcja-

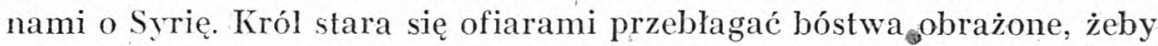
odwróciły zarazę i przepędziły ją do krajów wrogich Hetytom. Jeżeli bowiem, tak grozi król, zaraza dalej trwać będzie, tedy wszystko wyginie i nie będzie nikogo, ktoby jeszcze mógł się troszczyć o bogów, to znaczy, że bóstwa same sobie tylko szkodzić mogą.

Historyka, jak i religioznawcę ciekawi w tych tekstach szczególnie ważna sprawa, jak ów król wzgl. autor tekstów łłumaçzy przyczynę, dla której kraj tak ciężką klęską został nawiedziony. Za pomocą mantyki, inkubacji dowiedział się król, że chodzi w tym wypadku o złamanie przysięgi; według jednego tekstu dopuścili się jej książętá i dostojnicy państwowi, jak i ojciec króla względem jednego z członków dynastii królewskiej, który został zamordowany; według innego tekstu dopuścili się tylko Hetyci złamania przysięgi, ktora obowiązywała Egipcjan i Hetytów z racji zawarcia jakiegoś układu. Wiemy z dokumentów, zawierających tekst polityczny traktatów państwa Hatti, jak ważną rolę odgrywają w nich przysięgi ${ }^{28}$ ). Wasal króla hetyckiego zostaje na każdy nowy punkt kontraktu zaprzysiężony; w razie gdy wasal kontraktu nie zachowa, łamie on kontrakt i ,chwycą go bóstwa przysięgi“, których jest bez liku. Przysiega wówczas składana przed bóstwami połączona była ze składaniem ofiar w Babilonii, jak i u Hetytów, a więc była wyrazem kultu. I tutaj u Hetytów, jak widzimy,

25) A. Götze, Kleinasien, 1933, str. $162 \mathrm{nn}$.

26) J. Friedrich w „Der Alte Orient“ t. 24, 1925, zesz. 3.

27) Kleinasiatische Forschungen - A. Götze, t. I, 1927, str. 161-251.

${ }^{28}$ ) por. Mitteilungen d. Vorderasiat. ägypt. Gesellsch. t. 34, 1930, zesz. 1. 
rozpatrywano wydarzenia historyczne ze stanowiska religijnego w pojęciu starowschodnim. Słusznie zauważa A. Götze ${ }^{29}$ ), że bóstwa źcigają lamiących przysięgę nie dlatego, że moralny porządek świata zostaje przez złamanie przysięgi naruszony, ale dlatego, że bóstwa czują się obrażone zniewagą im wyrządzoną. Dokumentów historycznych hetyckich, opracowanych na modłę wyżej omówionej kroniki Weidnera, dotąd nie znaleziono.

Przeprowadzone w powyższym szkicu porównania historiografii biblijnej ze starowschodnią wykazały, że zainteresowanie przeszłością dziejową istniało tak u Izraela, jak i $\mathrm{u}$ innych narodów starowschodnich. U żadnego $\mathrm{z}$ nich nie można mówić o rozwoju historiografii w naszym znaczeniu. Dziejopisarstwo biblijne St. Testamentu nosi charakter religijno-wychowawczy; nie zachował się nam żaden dokument z świeckiej historiografiii izraelskiej, prócz materiału przejętego przez autorów biblijnych. Natomiast u innych narodów. starowschodnich rozwinęła się stosunkowo obszerna annalistyka, częściowo religijnie ubarwiona; bardzo słaba natomiast jest u nich literatura historyczna o "głębszym" ujęciu religijnym. Historyczna literatura biblijna przewyższa wszelkie podobne opracowania świata starowschodniego w tej mierze, jak góruje monoteizm etyczny autorów biblijnych nad politeizmem wzgl. panteizmem starowschodnim. A trzeba sobie uprzytomnić, że panteizm ten nosi cechy wiary w fatum czyli przeznaczenie ${ }^{30}$ ). Przemáwia za tym jeszcze inny rodzaj literatury, nazwany przez asyriologów „Omina“, która zajęła się również postaciámi historycznymi już królami Sargonem Starszym i Naramsin'em. Wydarzenia, które zaszły za lich panowania, stanowią wyroçnie na przyszłość; co zaszło w przeszłôści, powtórzy się pod tymi samymi warunkami i w przyszłości ${ }^{31}$ ).

Ks. JOZZEF JELITO

29) A. Götze, 1. c., str. 162.

80) por. „Ruch Bibl.“ I, str. $21 \mathrm{nn}$. i $144 \mathrm{nn}$.

s1) Zeitschr. f. ASS. t. VIII, str. 18. 